\title{
COLD MEMORIES
}

BY LAURENCE RAPHAEL BROTHERS

$\mathrm{T}$

The dead crawler loomed before me on the blasted, rocky plain, an oblong grey block on treads, dark canopy frosted over on the inside. This was as far from Rock City as you could get and still be on the asteroid, 200 kilometres out. I jacked a booster cable from my own crawler into the power port of the dead one and opened the outer door. I had to steel myself before cycling the lock. But kwuh is kwuh and this was my job. The inner door unlatched, and there it was: a dead body, frozen solid, sitting cross-legged with a tablet in its hands.

If the prospecting expedition you've saved up for half your life to go on has been a bust, maybe you override your crawler's low-power warning. Maybe you fire one plasma lance too many to assay yet another worthless nickel-iron lode. And then maybe you discover you don't have enough kilowatt hours to make it back. Too bad. When you're well overdue, Admin sends me to find and recover your crawler.

It's not a job for sensitive people. What I should have done is ignore the body. When the crawler recharged, it would return on autopilot. Bots would clean the cabin and recycle the corpse. But even through the layer of frost I could tell: this guy was old. Gen-1 old. I gritted my teeth, worked the tablet out of his dead, frozen fingers and took it back to my own ride. The recharge was quick. I gave the prospector's crawler some time before I followed it back to Rock City. I didn't want to have to see it alongside the whole way, knowing what was inside.

The tablet woke to my touch. The screen showed a small child. On Earth. Plants everywhere. The kid was hugging some kind of animal or petbot that was licking his ear. There was a textbox on top of the image. "For whoever finds me."

I wished he hadn't left anything behind. I didn't want my job to leave any marks. When I got home, I was going to the nearest chonnery to binge the memory of that frozen corpse out of my head. But I tapped the screen anyway.

The tablet opened a gallery of images and short video segments, all from Earth. I was gen-3, myself. My parents had no kwuh to speak of, so I grew up in a creche like most kids. I'd never known anyone who'd lived on Earth. Gen-1 was mostly dead by now.

\section{Time to go home?}

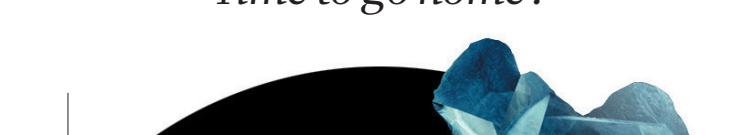

Council made LongReach exocorp settle a million refugees. They built Rock City as a depot for their bot miners to work the asteroids. Settling refugees was an afterthought.

After the prospector arrived here, there were no more images, no more videos. Everything was text, mostly about how much he hated Rock City. But everyone in Gen-1 hated it; we've only recently got to the point of affording a few luxuries. I almost skipped the most important bit. He hit it rich before I was even born. A 750,000-kilowatt-hour bounty from LongReach for a lode of pure iridium. He'd achieved the Rock City dream. So why was he out here frozen to death? He wanted to go home. To a ruined, blighted planet, but home, nevertheless.

Sol 256, 2142. Took six months for LongReach to answer my enquiry. That's why they planted us so far off. So we can't bother them, so we'll be forgotten. They say it's a million kwuh for a spot on an inner system freighter. And then another 500,000 for a residency at the Spitzbergen climate-monitoring station. The temperature has dropped 0.1 Celsius since 2130: there's hope for the future! The iridium bounty would cover my costs ten times over if it was in marsbucks instead of kwuh. Bastards. Still, one more strike is all I need.

The final entry. I didn't want to read it. But I had to.

Sol 18, 2185. I have to accept it. I'm never going home. The dream is over for me. For you, though - if you're reading this - open the battery case on this tablet. It's all I have left.

I almost didn't do it. Too sensitive, I guess. But I found two items. First, a plastic slip with an account number and passcode. Second, a frail, brittle blossom, just a hint of pink left in it. I looked it up online: it was a dried rose flower. The account turned out to have almost the whole bounty the prospector had earned. Mine, now. The flower - well, it didn't mean much to me at first. But I checked the latest climatology reports. Another half-degree drop in the past 40 years. Maybe the planet is healing. Maybe I'll take that flower back to Earth someday. Maybe I'll see roses blooming there myself. If I strike it rich ... late to choose a nice destination like Mars

ONATURE.COM Follow Futures: y) @NatureFutures $f$ go.nature.com/mtoodm or Luna. He wound up one of the first inhabitants of Rock City here in the Neptune Trojans. Mars
Laurence Raphael Brothers is a writer and a technologist. For more stories, visit his website, https://laurencebrothers.com. You can follow him on Twitter: @lbrothers. 